\title{
Research on Michelangelo Art Creation and Platonic
}

\author{
Yiting $\mathrm{Ge}^{1}$ \\ ${ }^{1}$ Nanjing Foreign Language School, Nanjing, 210000
}

Keywords: Michelangelo; art creation; Neo-Platonism

\begin{abstract}
Neo-Platonism was one of the most important ideas in the Renaissance, and it had a profound influence on the artistic creation of many artists. Michelangelo was one of them. For Michelangelo, the arts and poetry expressed are praising a perfect world. It is believed that the ideal world is the real reality. Therefore, Michelangelo's artistic creation hopes not only to get rid of the shackles of the flesh and to move toward a more noble realm, but also hopes to show a perfect and harmonious spiritual world through artistic creation; it has deep philosophical contemplation, thinking about the universe and the soul. The questioning has great enthusiasm and perseverance. His philosophy pays more attention to the inspiration and neglects the external impression. He believes that matter is the blasphemy and prisoner of the spiritual world and it is necessary to obtain spiritual relief through tragic rebellion. The expression of neo-Platonism in Michelangelo's works of art is very common. The conflict between abstract speculation and artistic inspiration can often be seen in his works. The conflict between this thinking and inspiration is analyzed to explore the art of Michelangelo's creation. The neo-Platonist thought is of great significance. This paper mainly discusses and analyzes the embodiment of Neo-Platonism in Michelangelo's artistic creation.
\end{abstract}

\section{The Intension of Neo-Platonism}

Neo-Platonism was a complex philosophical manifestation from the very beginning. After a long period of development, its ideological connotation was mainly reflected in the following aspects:

First, there are multiple levels from high to low. The higher the level is, the higher the degree of perfection is. On the contrary, the perceivable physical world is at the lowest level, and the higher level is derived at the lower level, but the derivation is not a process of time and space. Secondly, the derivation of Neo-Platonism as the supreme existence is a supreme principle, but the derivation transcends any conceivable reality, without restriction or total uncertainty; even derivation cannot be described as being, which represents the source of all fulfillment. Return to the ultimate goal, and derive a structured real world. Thirdly, each layer has an image or performance that is one level high. The level of existence is a uniform level. It can be said that the architecture of the entire Michelangelo theory runs through the relationship between the prototype and the image. Fourth, the existence of each level of derivation establishes its actual nature. When returning to the next level, it must be accomplished through the operation of meditation aspirations. Therefore, Michelangelo embodies the characteristics of the dual movements of appearance and return. Finally, the supreme principle is indefinite and absolutely pure. It must be combined with the mind to fully understand it. This fusion can neither be imagined nor described. Higher levels of things are more realistic than lower levels of things [1].

\section{The Neo-Platonism in the Heart of Michelangelo}

In Renaissance Italy, many neo-Platonic scholars emerged. At that time, there was a lot of popular language of philosophical knowledge in Italy. The influence of neo-Platonism became more and more obvious. Michelangelo was no exception; and Michelangelo and the then The main philosophical thinkers maintain close contact. Although they do not have any monographs related to neo-Platonism, they can clearly feel the influence of neo-Platonism through their artistic works and written poetry. The most common thing in Michelangelo's poetry is philosophical content, and Michelangelo's philosophical framework mainly comes from his artistic practice. Therefore, 
compared with other scholars, Michelangelo's philosophical thinking shows more obvious broadness. In general, the reflection of neo-Platonism in Michelangelo's works of art mainly reflects two aspects. On the one hand, Michelangelo believes that the ideal world is the real reality. The opposite is the perceptual material world. Image, and all things are God's source, all levels under God are emulating the perfect character of the artist. In artistic creation and poetry creation, the master pursues the highest perfection in the world of expression and chanting spirit, and this An ideal is also the ideological foundation of Michelangelo's neo-Platonic literary creation. On the other hand, the impact of the small universe on Michelangelo's influence is also very far-reaching. Michelangelo believes that artists can express the beauty of the concept world by depicting the sensual beauty of matter, while "man" is the epitome of the universe, and it possesses reason. The soul, whether it is spirit, material or form, has reached a high degree of harmony, so Michelangelo is very obsessed with body art and pursues the noble realm of expressing his spirit with his body and strength throughout his life; but he also knows that only The soul was freed from the imprisonment of materialism to achieve the spiritual noble level. Therefore, the consciousness of the soul of reason in Michelangelo's later works is more and more obvious. Although Michelangelo hopes to achieve spiritual breakthroughs through artistic creation, he also hopes to reflect spiritual perfection and harmony through a perceptual beauty world. This seemingly contradictory proposition is precisely what Michelangelo formed about neo-Platonicism. With his unique insights and experiences, he hopes to find himself through the abstract idea of beauty and appreciate the pure beauty that people think of. Therefore, Michelangelo accurately interprets the human body and strives to accurately express the beauty of harmony. Through the methods of distorting and deforming, he expresses the symbolic meaning of the soul and gives his works more strength and soul reason [2].

\section{The Embodiment and Penetration of Neo-Platonism in Michelangelo's Works}

Michelangelo's works include sculptures, paintings, poetry, etc. Here, taking Michelangelo representative as an example, he focuses on the reflection and infiltration of Neo-Platonism in his sculptures and paintings:

Mentioned above, influenced by neo-Platonicism, Michelangelo hopes to be fully expressed through the beauty of art and eulogizes mankind with a rational soul. Michelangelo showed a strong neo-Platonism ideology, with the guiding ideology of "self-concentration of the soul and self-contemplation". Drawing characters often have tension and torsion that are radiated from the inside out, and the soul has to get rid of matter. For example, Michelangelo's earlier representative painting "The Holy Family" in his early paintings, Vasari referred to him as "a very fine and perfect work." The work was created by Michelangelo on the commission of Angelo Toni in 1503. As a traditional theme, it mainly depicts the Virgin, St. Joseph and the baby Christ, but in this work the three religious images are completely The way in which ordinary folk figures are presented shows that the work is a carpenter's family and reflects a secular and harmonious scene through the dramatic combination of three characters. The work uses a pyramidal composition, which is stable, powerful, compact and harmonious. The Virgin Mary sits back and highlights the spatial sensation of the characters before and after. The location of St. Joseph and the Holy Child is slightly higher, making the picture more layered. According to Michelangelo's understanding of the beauty of the human body, it depicts the strong and powerful characters of the family. Even the nude young people in the background can see that Michelangelo's fascination with body changes can be seen in Michelangelo's Words, the human body is the best way to express beauty. Whether it is a meticulous external image or a coherent action performance, or the inner state of a character, is Michelangelo's display of beauty. This beauty is not only the beauty of the senses, the beauty of matter, but also the rational behind the balanced formal beauty. In Michelangelo China and the United States were endowed with infinite power, and Michelangelo integrated physical beauty and spiritual beauty in the human expression of reality [3].

Michelangelo's love of sculpture made him a successor to his predecessors' sculpting techniques. Although his frescoes are marvellous, he has always been a sculptor. He created his own unique 
sculpture style. Michelangelo's works have a strong internal strength. This kind of power makes the statues show a fundamental tragic nature. He is good at using the rotation, exaggeration, and distortion to express the internal strength of the human body. The volume form expresses a silent but yet fierce resistance, the two restraint and balance each other, this strong and powerful guidance of power makes his statue work has a complete, full and moving highlights. Michelangelo believed that the soul was struggling in matter, material and physical bound the soul, and through carving it was possible to release the soul from the stone. The conflict between the two gave life to the sculpture. Michelangelo followed the artistic style of "full and harmonious" in the Renaissance and praised the perfection and greatness of the soul. At this time, the artist concentrated on the aesthetics of beauty and nature in his works, such as "David", "Dionysian Bacchus", "The Virgin Mary". Later, the artist experienced emotions, artistic creations and life experiences. The creative spirit began to focus on the independent awakening of the soul, the conflict between the soul and the material, and the distortion of the body was full of infinite power. The soul formula was trapped in the body. For example, the design of the Medici family burial chamber and the burial chamber of Julius, and the "final trial" in the Sistine Chapel, and the different versions of the "Mourning Christ" etc., whose late works are more inclined to seek for souls. In the path of liberation, Michelangelo's late period was not satisfied with the beauty of reason and the beauty of natural material, and her pursuit of the beauty of the soul became stronger and stronger [4].

Due to Michelangelo's sculptural works, this article uses Rome's "Mourning Christ" as an example. Michelangelo Rome's "Mourning Christ" was carved in 1498-1500 at the invitation of the French Cardinal Jean Bihaer Ragenolas for the Vatican Church, "Mourning Christ". Stone is a material about 1.15 meters high. This work is a typical representative of the Renaissance classical classicism. Its beautiful form, complete carving, and shiny appearance make it possible for the mother to express her serenity and gentleness when receiving his son's martyrdom. Christ was detached from the cross and rested on the lap of the Virgin Mary. Her right hand was placed under Christ's knees to support the weight of her upper body [5]. Christ leaned back on his mother's arm. The face of the Virgin was drowsy and looked sadly and peacefully at the dead. son. Often the Virgin Mary is carved into a girl or young woman much younger than she really is, reflecting the beauty of youth that does not decline. This beauty symbolizes divine maternal love. Christ is a mortal body. It has experienced long years of hardship. His time and experience have contrasted with the Virgin's eternal beauty of youth. "One life, one death, one movement and one quiet, reflecting the unity and artistic harmony from the opposition. This limited harmony seems to be an infinite harmony between the universe and eternity." The tragic theme, expressed in a noble and serious image, supports the neo-Platonic thought of the relationship between soul and body [6].

\section{Conclusion}

In short, neo-Platonism has had a profound influence on Michelangelo's artistic creation throughout his life. Whether he is carving or painting or poetry, he has spent his whole life pursuing the perfection of the ideal world. He has paid more and more attention to the soul in his later years of creation. His poetry, paintings, and sculptures not only express the beauty of art, but also reflect the neo-Platonic concept of pursuing freedom of the soul and getting rid of material constraints. Therefore, Michelangelo's neo-Platonic literary creation has played an important role in the artistic development of later generations.

\section{References}

[1] Zhang Liguo. Power • Sublime - Tragic Beauty - Talk about Michelangelo and his art [J]. Art exploration. 1990, (2):201

[2] Zhang Ying. The two philosophical cornerstones that influenced Michelangelo's sculpture creation: Neo-Platonism and Christian theology [J]. Journal of Shantou University (Humanities and Social Sciences). 2003, (1):309 
[3] Zhou Chunsheng. On the individual spirit of the Renaissance during the Renaissance [J]. Learn the sea. 2008, (1):643

[4] Li Yaping. Luo Dan inherits and innovates traditional sculpture art modeling techniques [J]. Journal of Inner Mongolia Normal University. 1998, (3):163

[5] Liu Dongmei. Sistine Chapel celestial painting and appreciation of the "final trial" [J]. Art and Design (Theory). 2007, (3):96

[6] Ma Yuelan. The Infiltration of Religious Art - Michelangelo (Moses) Appreciation [J]. World religion and culture. 2008, (1):537. 